\title{
The Role of ICT Literacy Opinion on ICT Self- Efficacy and AR Opinion on Teacher Education Students
}

\author{
Astian Artiningsih ${ }^{1, *}$ Paidi $^{2,}$ Insih Wilujeng ${ }^{3}$ \\ ${ }^{1}$ Master of Natural Science Education, Faculty of Mathematics and Natural Sciences, Universitas Negeri \\ Yogyakarta, Indonesia \\ ${ }^{2}$ Department of Biology Education, Faculty of Mathematics and Natural Sciences, Universitas Negeri \\ Yogyakarta, Indonesia \\ ${ }^{3}$ Department of Natural Science Education, Faculty of Mathematics and Natural Sciences, Universitas Negeri \\ Yogyakarta, Indonesia \\ *Corresponding author. Email: astianartiningsih.2019@student.uny.ac.id
}

\begin{abstract}
This study is a descriptive quantitative research. Research is conducted to show teacher education students perception about ict literacy opinion for ict self-efficacy and augmented reality opinion. Data collected through a questionnaire which a questionnaire purposed to measure perception about ict literacy opinion, self-efficacy, and augmented reality opinion on teacher education students.. This study use purposive sampling and there were 62 teacher education students. The result of this study showed that the questionnaire has a cronbach's alpha score of 0,662 and based on the data, the teacher education students have shown a positive high perception about ICT literacy opinion in overall success in using technologies at classroom learning, but some respondent still lack experience using augmented reality. The result showed that the ability of ict literacy opinion on the indicators is $84 \%$, on self-efficacy is $80 \%$, and on augmented reality opinion is $73 \%$.
\end{abstract}

Keywords: ICT literacy, ICT self-efficacy, Augmented reality

\section{INTRODUCTION}

The recent decades we have been rapid growth in the sector of information and communication technology (ICT) development. Development of technology have been infiltrating all parts of everyday life, change and modify the way people communicate, work, spend their leisure time and study. ICT manipulate an important role in all sectors include a society and the school a place who should be able to adequate the needs and overcome the difficulties students have, preparing them for the constant changes that technology provide. As [1] states that the community expects school goals in line with the changes and needs of society. The emergence of new technologies in the world of education open up the possibility of new experience for teachers to innovate in teaching methods and allows students to facilitate learning and improve their competences. According [2], based on the results of a case study on student motivation in classrooms with and without the use of
ICT, that students are encouraged to use technology and focus on practices that are integrated with are curriculum. Students are also encouraged to develop skills for collaboration, sharing, and developing their creativity. The content created by teachers must be adapted to the interest of students without disregrad their previous experiences in using technology inside or outside the classroom. The reality of education can be recorded through the presence of new technology; students can be motivated by unusal experiments. So it becomes a challenge for teacher to create new strategies that underwrite use of technology, where students will be interest to follow learning and improve their academic competence.

According to [3] it was concluded that the technology would be successfully used by educators in a generative and constructivist way, one of which was their effective beliefs in ICT. [4] support this opinion, and there is a positive relationship between educators' ICT self-efficacy and use of computers in their 
classroom. ICT self efficacy show beliefs about the ability to complete tasks with use of computers/ICT [4]. Some argue that the pedagogical use of technology is ineffective in contemporary classrooms, this is the cause of low teacher ICT literacy levels [3]. In [5] states that teacher who have high ICT self efficacy affect the use of technology. Likewise, the lack of self efficacy affects the increasing use of technology by educators in it use in classrooms [6]. [7]. ICT selfefficacy is a measure of educators using technology [8]. Furthermore, the use of technology in the classroom is more significant than other attitude factors such as benefit usefulness, feelings of use, and function using of ICT [7].

The conceptualisation of ICT self-efficacy is belief in the self beliefs [9], their own ability and competence in using ICT effectively, to make academic assignments successful is the definition of self-efficacy. Educators with higher ICT self-efficacy are most like to use ICT in their classroom and are least likely to suffer from ICT related anxiety [3]. [10] and [11] found that ICT self-efficacy is a perception of one's abilities to use ICT. Investigate several perceptual factors, [12] and [13] suggests that individuals with high computer skills will be more successful in using technology and high responsibility than individuals who have low perceptions of the ability to use computers. It can be concluded that they will be more open to using innovative technology and interested in trying new teaching methods that link ICT. This view can be described as a to special capabilities educators feel should deliver lessons that integrate ICT. [14] argue that the level of confidence in the use of ICT is an important measure of use of ICT in teaching. Furthermore, [15] study at Turkish stated that those with higher perceptions of ease of use ICT tended to have high self-efficacy. This is due to the following factors: perceived benefits, ease of use, and social environmental influences. This suggests that positive perceptions of using technology effectively have a positive effect on how they reduce the perceived difficulty of using technology. [15] also found ease of use and confidence also had influence on the educator to use ICT.

Nowadays a widely adopted trend to use of Information and Communications Technologies (ICT) in educational environment and learning. Learning Management Systems (LMS), such as Moodle is an essential component of each and every school and more recently use of mobile devices has also spread, particularly in Higher Education institutions [16]; [17] ICT are particularly useful in helping institutions to develop an "Active and Student Centered Learning" (ASCL). One of the most developed technology in recent time and with greater expectations for the near future is Augmented Reality (AR). This resource beginning to have an increase application in education. Among its advantages there is the possibility of view images and three dimensional scenes of great realism with the consequent impact on student motivation and better understanding of the topics studied. It is also important to bear in mind that this techniques can be implemented with use of mobile devices that students usually bring into class (tablets and smartphones), which significantly reduces the need for acquisition of expensive equipment by institutions.

Factors related to self-efficacy and use of ICT are essential for better teaching. The factors were found can predict the effectiveness of teaching dan learning [18]; [19]; [6]. This study found that the effective use of ICT by teacher has an inclination to create a more meaningful learning [20]; [21], allowing students to investigate furhter as they try to understand the subject content. In detail, this research will show the level category of achievement of ICT literacy opinion, ICT self-efficacy, and opinion on the use of technology in augmented reality.

\section{METHOD}

This article reports on self- efficacy of the level of basic ICT literacy opinion and opinion connected with augmented reality. There were 62 respondents who are the students of pedagogical studies. The average age of the respondents was 22.3 years, with standard deviation is 4.232. A survey was administered in the third term of the school calendar in August 2020 in university in the D.I.Yogyakarta Province. Because this study explore educators opinion of self-efficacy and use of ICT at any given time for teaching and learning, the survey design was deemed appropriate for such an investigation.

The research was purpose, the scale measuring the self efficacy of ICT literacy opinion was used. Each item used a classic 5 degree Likert scale which enable self-efficacy and the determination of the frequency of use of augmented reality solutions during the last year. This questionnaire use closed questions developed from previous studies [28]; [29]. In order to see the indicators achievement, table of achievement level of each indicator is utilized and provided on table 1. 
Table 1. Category of achievement level of each indicator [32]

\begin{tabular}{|c|c|}
\hline Percentage $(\%)$ & Criteria \\
\hline $81.25<x \leq 100$ & Very High \\
\hline $71.50<x \leq 81.25$ & High \\
\hline $62.50<x \leq 71.50$ & Moderate \\
\hline $43.70<x \leq 62.50$ & Low \\
\hline $0<x \leq 43.70$ & Very Low \\
\hline
\end{tabular}

\section{DATA ANALYSIS}

This research use SPSS version 22, analysis of data include a reliability test, a homogeneity test, a normality test, and descriptive statistics.

\subsection{Reliability Test}

Table 2. Category of achievement level of augmented opinion

\begin{tabular}{|l|c|c|}
\hline \multicolumn{1}{|c|}{ Item Question } & Percentage (\%) & Criteria \\
\hline I can learn to use a computer or cellphone for my teaching and learning process & 91 & Very High \\
\hline I have a laptop and smartphone at home & 95 & Very High \\
\hline I've heard of an application technology called augmented reality (AR) & 63 & Moderate \\
\hline $\begin{array}{l}\text { I have experience accessing Augmented Reality technology taught by relatives } \\
\text { or by myself }\end{array}$ & 52 & Low \\
\hline Augmented Reality technology can only be used in schools & 47 & Low \\
\hline $\begin{array}{l}\text { Learning with Augmented Reality offline or online is not effectively } \\
\text { implemented }\end{array}$ & 47 & High \\
\hline $\begin{array}{l}\text { Learning Science using AR makes it easier for students to be more active } \\
\text { Learning Science using Augmented Reality makes it easier for students to } \\
\text { understand abstract phenomena }\end{array}$ & 85 & Very High \\
\hline $\begin{array}{l}\text { AR which is equipped with audio and animation features adds to the interest in } \\
\text { learning science }\end{array}$ & 87 & Very High \\
\hline $\begin{array}{l}\text { AR in learning aims to increase the technological, information and } \\
\text { communication skills of students }\end{array}$ & 86 & Very High \\
\hline \begin{tabular}{l} 
Less sophisticated smartphone features cause constraints to access AR \\
\hline
\end{tabular} & 79 & High \\
\hline
\end{tabular}

Realibility test show 0,662 of 55 item questioner. Meaning the questioner is reliable.

\subsection{Homogeneity Test}

Homogeneity test can be seen in the sig value. The sig value shows 0,000 so that the question item is homogeneous with a Levine statistic of 64,180 .

\subsection{Normality Test}

To ascertain the nature of data distribution on a scale of measurement used, normality tests are carried out [30]. This help in determining the appropriate statistical analysis for use in this study. Data distribution can be checked using Kolmogorov Smirnov (KS). The research using Kolmogorov Sminorv (K-S) on each variable, so that three variables can be concluded to have normal data. For AR opinion is 0,062 , ICT literacy opinion is 0,061 , and ICT self-efficacy is 0,070 .

\section{RESULTS AND DISCUSSION}

\subsection{Augmented Reality Opinion}

Table 2 present descriptive statistics related to the opinion of the student with technology augmented reality during the last year. A data show basic descriptive statistics for opinion of use AR and perception about AR. The scale for the data in Table
2 was between 1 - very never and 5- very often. Question item taken 10 representing items. It can be seen that of the five items the highest value of Kolmogrov-Sminorv in item 47 with a value of 0,071 , and the lowest is on item 52 with a value of 0,052 . From item 47 regrading the question "ever heard of AR application technology" on average answered on a scale of 3 (doubtful). This relate to item 48 where question about the experience of accessing AR shown 
by studentds answered on a scale of 2 (never). A item question of $\mathrm{i}$ have experience accessing Augmented Reality technology taught by relatives or by myself shown criteria is low. That's mean many teacher education student never used augmented reality.

According [31] inference that the use of augmented reality systems in the referred projects promotes the success of the learning process, increasing concentration and essentially motivating students to overcome their learning difficulties. The educational field has already started introducing augmented reality technology. According to [22] the challenge is focused on achieving and developing the appropriate experience to support learning experiences. It means that the challenge is not only the introduction of technology in the classroom but mostly on how to use it to enhance student learning. According [3], in a study with more than thirty higher education students of a geography subject at the
University of Washington on the theme the relationship between the earth and the sun concluded that there is big potential in using augmented reality display interfaces in education. The results show that after carried out the exercises student make less mistakes and a significant improvement in understand the subject contents was confirmed. The authors concluded that the augmented reality introduction in the classroom improved the overall quality of the teaching and learning experience.

\subsection{ICT Literacy Opinion}

Figure 1 presents category of achievement level of ICT literacy opinion in six key area. The scale for the data in figure 2 is the respondent's own ICT literacy opinion and is between 1- very poor and 5- very strong.

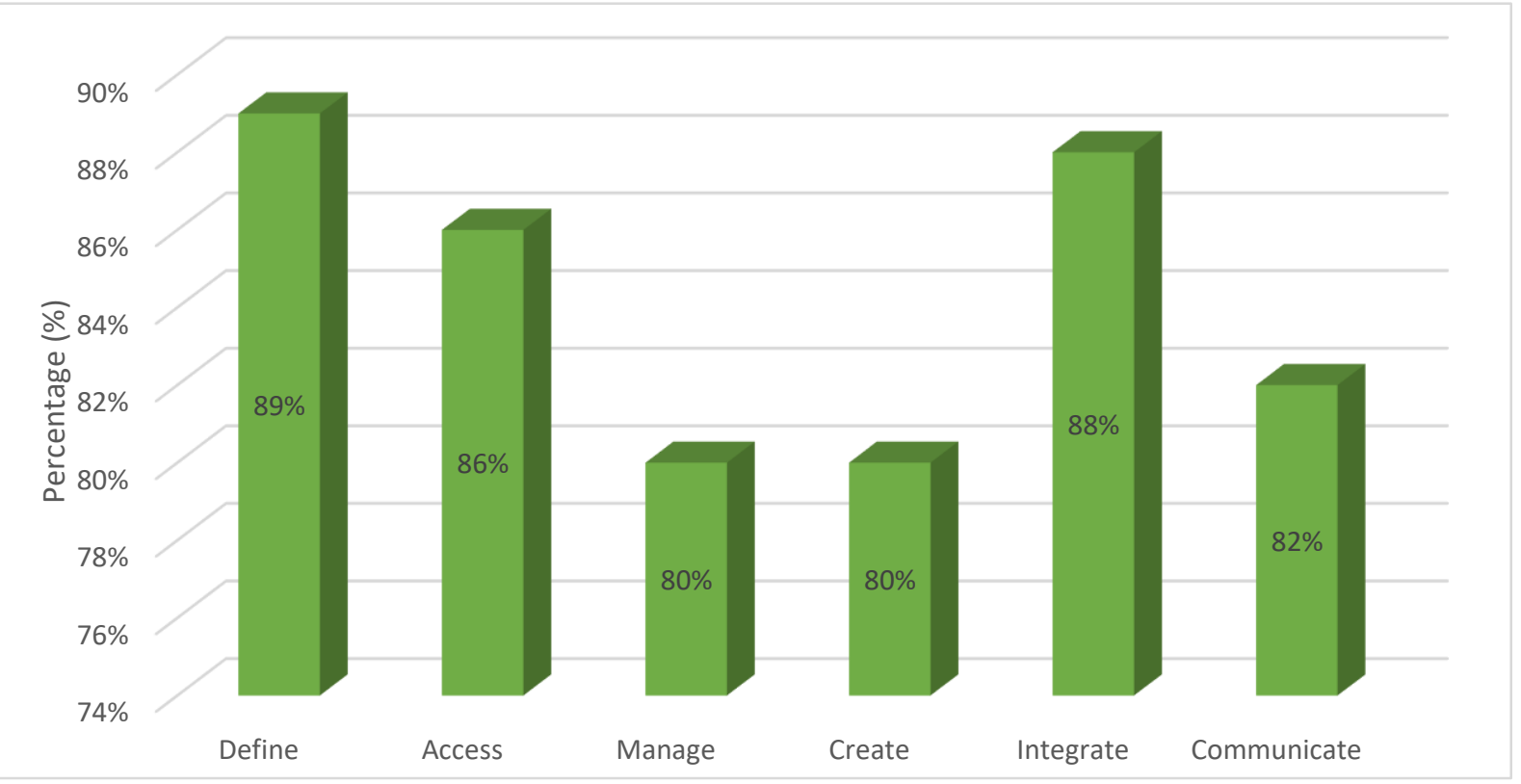

Figure 1 Level of ICT literacy opinion

Use of multimedia which is the integration of various different forms of media, the use of multimedia is proven to be effective for improvement in learning process [27]. Educator consider the use of ICT to facilitate teaching in the classroom. Therefore, they have include the use of multimedia such as images, audio, and video in the learning process. Therefore at ICT literacy on manage indicator. The majority of educator indicate they use different media to improve quality of content $(80 \%)$ and to improve learner activities (75\%). Figure 1 show the highest indicator value of respondents is define. Thismeans that as many $89 \%$ of respondents are able to define ICT, of course if they are able to define ICT then other indicator are expected to have a high value such as indicatore of access and integrate. Figure 1 at integrate indicator resonate with [26]; [19] finding that the integration of technology is not fully usable because technology is only used to represent and present the content of certain subject. Figure 1 show a result is $88 \%$ at integrate indicator show that teacher education uses tools to simply present information in the form of better and more attractive media even though they have ICT that can be used as cognitive tools. However, it is much better than 
traditional learning which can reduce the quality of teaching.

Related to create indicator, $80,3 \%$ of respondents claim to use ICT such as educational website as teaching materials for directed learning using strategies such as cooperative learning and they were able to make media using available technology such as microsoft office or adobe. As many $74 \%$ of respondents agree/strongly agree that they use ICT such as simulation software as cognitive tool that help to stimulate critical thinking. About $78,2 \%$ of respondents using collaborative technology such as social media platforms, and Google Docs to facilitate student to work together in small groups to interact with the educator. According a figure 1, it is evident that most educators are use technology for the delivery of learning that allows students to work independently and effectively. This also relate to indicator of communication with percentage $82 \%$ of respondents are able to communicate what they have learned or used, for example disseminating new technology in education.

\subsection{ICT Self-Efficacy}

Figure 2 shows a result $(83 \%)$ of respondents confirm their ability to learn to use computer for teaching and learning processes. According the result is $83 \%$ of respondents with mean score 3,91 claim that they can easily teach classes in which they are required to use instructional technology. That's means the teacher education students have good academic competence regrading ICT, as evidenced by the survey that has been conducted which show the number with very high criteria. They clam that have the necessary skill to use technology for instructional purposes. Similarly, $78 \%$ with mean score 3,90 report that it is easy for them to find instructional technologies that are relevant for their teaching purposes on social resources indicator. This social resource indicator is an indicator that contains about asking for help from others. In this case the teacher education student asks for help to use technology, for example when teaching asks student to turn on the lcd projector. This shows that respondents are quite confident in the use of ICT in their calssroom. The majority $(78 \%)$ indicate that respondent are willing to learn how to integrate ICT in their classroom. Research on the use of technology has been found to increase ICT self-efficacy [25]. This implies that educators will be more effective in using technology and increased confidence in ICT for better teaching. The category of self-regulation indicator is high with a value of $78 \%$, this means that the ability to plan a learning activity among respondents is quite high, although there are still many who are not able to plan activities maximally, especially with use technology.

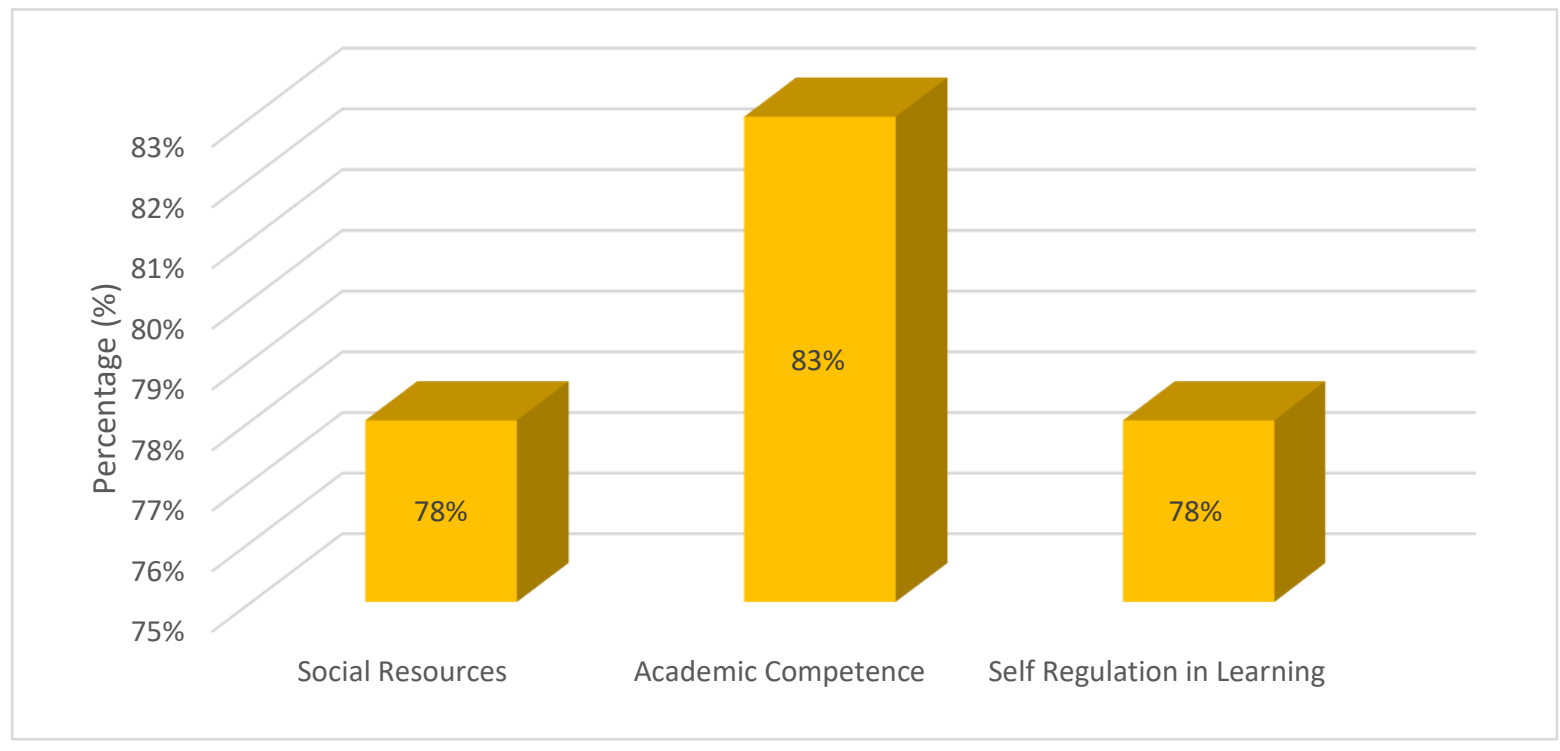

Figure 2 ICT self-efficacy

Data analysis shows that most educators feel confident using ICT for teaching and learning process. According on the percentage of respondents confident with the use of ICT for teaching and learning, they are confident that their behaviour would lead to successful attainment of their teaching objectives. This the perceptions educators have about their ability to use ICT in their classrooms contributes to reach of their 
teaching goals as they are likely to effectively use technology.

Similarly, lack of ICT self-efficacy can be one of the obstacles that hinder the use of ICT by educators. Otherwise, findings of this study show that teacher education students are ICT self-efficacy have strong correlation between ICT self-efficacy and use of ICT to supports teaching and learning. As [14]; [3] contend, when ICT can be used by educators effectively, learning will be successful and can increase the self-efficacy of educators. Educators response to the level of confidence in ICT self-efficacy show that they are confident in using ICT so that ICT literacy will increase as ICT self-efficacy increase. Therefore, their opinion of ICT are positive [24]. This corroborates [13] finding that individuals with high perceptions about computer and ICT in general are more successful at using technologies, are more willing to take responsibilities relating to use of ICT, and have higher intentions to use ICT in their classrooms.

\section{CONCLUSION}

Based on data found, its known that the teacher education students have shown a positive high perception about ICT literacy opinion in general are more successful at using technology, but some teachers education students still lack experience using augmented reality because the skill is moderate. Experience and professional development has been reported to enhance self efficacy. Therefore, has a potential to enhance educators ICT competence and their knowledge for effective ICT integration, and in turn has an opportunity to boost educators confidence and develop their efficacious belief about the use of ICT. Consequently, educators who are more competence to use ICT more frequently in their daily teaching practice.

\section{REFERENCES}

[1] C.E. Rêgo, ICT in The Compulsory Education Curriculum, Universidade Portucalense, Feb. 2012. Accessed on: Jul. 27, 2020. [Online]. Available:

https://repositorio.uportu.pt/bitstream/11328/145 2/1/TMTICE2012

[2] S.R. Sobral, Motivation Of Students With And Without Using ICT in The Classroom. Universidade Portucalense, Feb. 2012. Accessed on: Jul. 27, 2020. [Online]. Available: http://repositorio.uportu.pt/jspui/bitstream/11328 1516/2/TMI\%2032.pdf
[3] N. DiGregorio, Experiencing technical difficulties: teacher self-efficacy and instructional technology, in: C.B.Hodges (Ed.), Self-efficacy in Instructional Technology Contexts, Springer, Cham, 2018, pp. 103-117. DOI: https://doi.org/10.1007/978-3-319-998589_7

[4] K.S. Hong, M.L. Chai, K.W. Tan, U. Hasbee, L.N. Ting, ESL Teachers Computer SelfEfficacy, Attitudes Toward Computer and Classroom Computer Use, Pertanika Journal Social Science and Humanities 22(2) (2014) 369385.

DOI: https://doi.org/10.1016/j.heliyon.2020.e03730

[5] N. Thongsri, L. Shen, Y. Bao, Investigating Academic Major Differences in Perception Of Computer Self-Efficacy and Intention Toward ELearning Adoption in China, Innovation in Education and Teaching International 57(5) (2019) 1-13. DOI: https://doi.org/10.1080/14703297.2019.1585904

[6] D. Alt, Science Teachers' Conceptions Of Teaching and Learning, ICT Efficacy, ICT Professional Development and ICT Practices Enacted in Their Classrooms, Teaching and Teacher Education 73 (2018) 141-150. DOI: https://doi.org/10.1016/j.tate.2018.03.020

[7] N. Siyam, Factors Impacting Special Education Teacher Acceptance and Actual Use of Technology, Education and Information Technologies 24 (2019) 2035-2057.

[8] Y. Li, V. Garza, A. Keicher, V. Popov, Predicting High School Teacher Use of Technology: Pedagogical Beliefs, Technological Beliefs and Attitudes, and Teacher Training, Technology Knowledge and Learning 24(3) (2019) 501-518. DOI: https://doi.org/10.1007/s10758-018-9355-2

[9] A. Bandura, Self-efficacy: The Exercise of Control, Freeman and Company, 1997.

[10] D.R. Compeau, C.A. Higgins, S. Huff, Social Cognitive Theory and Individual Reaction to Computing Technology: A Longitudinal Study, MIS Quarterly 23(2) (1999) 145-158. DOI: https://doi.org/10.2307/249749

[11] S. Kerckaert, R. Vanderlinde, J. van Braak, The Role Of ICT in Early Childhood Education: Scale Development and Research on ICT Use and Influencing Factors, Eurean Early Childhood Education Research Journal 23(2) (2015) 183- 
199.

DOI:

https://doi.org/10.1080/1350293X.2015.101680

4

[12] V. Celik, E. Yesilyurt, Attitudes To Technology, Perceived Computer Self-Efficacy And Computer Anxiety As Predictors Of Computer Supported Education, Computers \& Education 60 (2013) 148-158. DOI: https://doi.org/10.1016/j.compedu.2012.06.008

[13] T. Teo, F. Huang, C.K. Hoi, Explicating The Influences That Explain Intention to Use Technology Among English Teachers in China, Interactive Learning Environments 26(4) (2018) 460-475.

DOI: https://doi.org/10.1080/10494820.2017.1341940

[14] G. Sang, M. Valcke, J. van Braak, J. Tondeur, Student Teachers' Thinking Processes and ICT Integration: Predictors of Prospective Teaching Behaviors with Educational Technology, Computers \& Education 54(1) (2010) 103-112. DOI:

https://doi.org/10.1016/j.compedu.2009.07.010

[15] O. Baydas, Y. Goktas, A Model For Preservice Teachers' Intentions To Use ICT in Future Lessons, Interactive Learning Environments 25(7) (2017) 930-945. DOI: https://doi.org/10.1080/10494820.2016.1232277

[16] U.R. Cukierman, S. Silvestri, M. Agüero, J. Drangosch, A student-centered approach to learning mathematics and physics in engineering freshmen courses, in: Proceedings of The 2018 World Engineering Education Forum-Global Engineering Deans Council (WEEF-GEDC), vol. 1, IEEE, Piscataway, New Jersey, 2018. DOI: https://doi.org/10.1109/WEEFGEDC.2018.8629733

[17] U. R. Cukierman, S. Silvestri, M. Agüero, J. Drangosch, Bridging the gap between first-year students and eEngineering: A novel application of mobile technologies for improving mathematics and physics learning, in Proceedings of The 2017 7th World Engineering Education Forum, IEEE, Piscataway, New Jersey, 2017.2 DOI: https://doi.org/10.1109/WEEF.2017.8467127

[18] A. Chigona, W. Chigona, Capability Approach on Pedagogical Use of ICT in Schools, The Journal for Transdisciplinary Research in Southern Africa 6(1) (2010) 209-224. DOI: https://doi.org/10.4102/TD.V6I1.117
[19] A. Aslan, C. Zhu, Influencing Factors and Integration of ICT Into Teaching Practices of PreService and Starting Teachers, International Journal of Research in Education and Science 2(2) (2016) 359-370. DOI: https://doi.org/10.21890/ijres.81048

[20] N. Entwistle, P. Ramsden, Understanding Student Learning, Nichols Publishing Company, 1982.

[21] B. Tanriverdi, Pre-service teachers' epistemological beliefs and approaches to learning, in: Procedia-Social Behavioral Sciences, vol. 46, Elsevier, Amsterdam, 2012, pp 2635-2642.

DOI:

https://doi.org/10.1016/j.sbspro.2012.05.538

[22] N.F.O. Veloso, Realidade Aumentada no Ensino: prototipagem com um manual escolar, Ph.D. dissertation, Departamento de Comunicacao e Arte, Universidade de Aveiro, Aveiro, 2011.

[23] B.E. Shelton, N.R. Hedley, Using augmented reality for teaching earth-sun relationships to undergraduate geography students, in: Proceeding of the Augmented Reality Toolkit, The First IEEE International Workshop, vol. 1, IEEE, Piscataway, New Jersey, 2002, pp. 1-8. DOI:

https://doi.org/10.1109/ART.2002.1106948

[24] C. Kim, K.K. Kim, C. Lee, M.J. Spector, K. DeMeester, Teachers Beliefs And Technology Integration, Teaching and Teacher Education . 29 (2013) 76-85. DOI: https://doi.org/10.1016/j.tate.2012.08.005

[25] H.A. Efe, The Relation between Science Student Teachers' Educational Use of Web 2.0 Technologies and Their Computer Self-Efficacy, Journal of Baltic Science Education 14(1) (2015) 142-154.

DOI: https://journals.indexcopernicus.com/search/arti cle?icid=1143044

[26] W.S. Shin, Teachers' Use of Technology And Its Influencing Factors in Korean Elementary Schools, Technology, Pedagogy and Education 24(4) (2015) 461-476. DOI: https://doi.org/10.1080/1475939X.2014.915229

[27] I. Shah, M. Khan, Impact of Multimedia-Aided Teaching on Students' Academic Achievement and Attitude at Elementary Level US China, Educational Review 5(5) (2015) 349-360. DOI: 
https://doi.org/10.17265/2161-

$\underline{623 X / 2015.05 .006}$

[28] L. Wang, P.A. Ertmer, T.J. Newby, Increasing Preservice Teachers' Self-Efficacy Beliefs for Technology Integration, Journal of Research on Technology in Education 36(3) (2004) 231-250. DOI:

https://doi.org/10.1080/15391523.2004.1078241 $\underline{4}$

[29] H.M. Al-Awidi, I.M. Alghazo, The Effect of Student Teaching Experience on Preservice Elementary Teachers' Self-Efficacy Beliefs for Technology Integration in The UAE, Educational Technology Research and Development 60 (2012) 923-941. DOI: https://doi.org/10.1007/s11423-012-9239-4

[30] K.S. Bordens, B.B. Abbott, Research Design and Methods: A Process Approach $\left(8^{\text {th }}\right.$ Ed.), McGraw-Hill, 2011.

[31] D. Sampaio, P. Almeida, Pedagogical strategies for the integration of Augmented Reality in ICT teaching and learning processes, in: Proceeding of the Procedia Computer Science, vol. 100, Elsevier, Amsterdam, 2016, pp 894-899. DOI: https://doi.org/10.1016/J.PROCS.2016.09.240

[32] Ermayanti, D. Sulisworo, Tingkat kemampuan berpikir kritis peserta didik setelah penerapan model pembelajaran Student Team Achievement Divisions (STAD) pada siswa Sekolah Menengah Atas (SMA), in: Prosiding Seminar Nasional Quantum, vol. 1, Universitas Ahmad Dahlan, Yogyakarta, 2016, pp. 175-181. 